\title{
Letting Down the Ladder or Shutting the Door: Female Prime Ministers, Party Leaders, and Cabinet Ministers
}

\section{Diana Z. O’Brien}

Indiana University

Matthew Mendez

\section{Pomona College}

Jordan Carr Peterson

University of Southern California

Jihyun Shin

University of Southern California

Tn October 2012 the Danish Socialist People's Party chose Annette 1 Vilhelmsen as its leader. With her ascension to power, women simultaneously headed all three of Denmark's governing parties for the

We are grateful to Claire Annesley and Susan Franceschet for organizing this special issue and providing invaluable feedback on early drafts of the manuscript. We would also like to thank the editors and the anonymous reviewers who offered helpful comments and suggestions during the review process.

Published by Cambridge University Press 1743-923X/15 \$30.00 for The Women and Politics Research Section of the American Political Science Association.

(C) The Women and Politics Research Section of the American Political Science Association, 2015

doi:10.1017/S1743923X15000410 
first time. Though an exclusively female-led coalition government remains exceptional, in developed democracies the number of female prime ministers and party leaders has grown in recent years. Since 2000, women have governed in Denmark, Germany, Finland, Iceland, New Zealand, and Australia and have commanded coalition partner parties in Austria, Ireland, and Sweden. Just as there are now more female leaders, governments are also nominating more women to cabinets than ever before. Women recently held half of all ministerial posts in Finland, Iceland, Sweden, and Spain. Female ministers are also serving in highprestige portfolios from which they were traditionally excluded, including finance and foreign affairs.

As women's presence in executive office grows, interest in both women's ascension to leadership positions (Jalalzai 2013; Murray 2010; O'Neill and Stewart 2009; Wiliarty 2008) and nomination to cabinets (Bego 2014; Claveria 2014; Davis 1997; Escobar-Lemmon and Taylor-Robinson 2005; Reynolds 1999) has also increased. At the same time, female leaders and ministers have largely been studied in isolation from one another, and little is known about the relationship between the two. This is a surprising oversight because party leaders play a central role in cabinet appointments and because of the conflicting expectations generated by prior research. While some scholars posit that female leaders increase women's access to top political posts (Davis 1997; Jacob, Scherpereel, and Adams 2014), others find no support for this claim (Krook and O'Brien 2012) or show that it is wholly attributable to selfappointments (Barnes and O'Brien 2015).

We provide the first empirical analysis of female leaders' effects on both the proportion of ministerial posts held by women and women's nomination to high-prestige portfolios. After examining the literature on women's cabinet appointments, we develop two competing sets of hypotheses linking female leaders and ministers in advanced parliamentary and semipresidential democracies. Our letting-down-the-ladder hypotheses posit that female prime ministers and coalition party leaders - particularly in left governments - are associated with women's increased appointment to cabinets and their ascension to high-prestige ministerial posts. In contrast, our shutting-the-door hypotheses suggest that the presence of female leaders - especially in nonleft governments - will result in the nomination of fewer women to (high-prestige) portfolios.

We test our competing hypotheses using data on female prime ministers, party leaders, and cabinet members in 15 countries beginning in 1980 . Our multilevel models with country-level random effects demonstrate 
that the presence of either a female prime minister or a female-led coalition party is associated with fewer female-held portfolios, particularly as compared to exclusively male-led left governments. Female leaders are also no more likely than their male counterparts to appoint women to high-prestige posts. In our discussion of these results, we posit that this is likely a consequence of the opportunities and constraints facing male and female leaders in parliamentary and semipresidential regimes. These findings thus offer an important contribution to the growing literature on women in executive politics and lay the groundwork for future research exploring the knock-on effects of women's ascension to leadership posts. Indeed, they highlight the need for additional qualitative and quantitative work assessing the motivations and incentives of male and female leaders across different political systems.

\section{TRENDS IN WOMEN'S ACCESS TO MINISTERIAL POSTS}

Women have traditionally held few ministerial positions and have been relegated to low-prestige portfolios with "feminine" characteristics (Davis 1997; Escobar-Lemmon and Taylor-Robinson 2009; Reynolds 1999; Studlar and Moncrief 1999). Their nomination to cabinets - and appointment to high-prestige posts - thus has major pragmatic and symbolic implications. Women's inclusion in government grants them policy-making authority that they were previously denied (Laver and Shepsle 1994), and the presence of female cabinet members is a key determinant of women's substantive representation (Atchison and Downs 2009). Beyond these important policy implications, the nomination of female ministers is an important indicator of gender equality in politics (Krook and O'Brien 2012). Women's continued exclusion from these posts indicates that men's grip on power remains firm, while their inclusion in cabinets signifies broader changes to women's status.

Though the appointment of female ministers is important for ensuring women's access to political power, there is also growing recognition that women's portfolio assignments can either reinforce or displace traditional gendered patterns of exclusion (Borelli 2002). Cabinet assignments are not created equal, and different portfolios vary with respect to their influence within the cabinet, the amount of media attention they garner, and the degree to which they provide a pathway to higher office (Krook and O’Brien 2012). Historically, the ministries allocated to women were rarely part of the most important "inner 
cabinet" (Davis 1997). While these portfolios often deal with areas that are central to the welfare state and of particular importance to female citizens (Trimble and Tremblay 2012), women's cabinet posts were often rendered "unimportant" by the criteria of political clout (Krook and O'Brien 2012). The appointment of women to high-prestige portfolios thus represents a highly visible break from traditional patterns of women's marginalization in the executive branch (Bego 2014; Escobar-Lemmon and TaylorRobinson 2005).

As scholars and practitioners alike have come to recognize the importance of female ministers, a growing body of literature examines women's nomination to cabinets and appointment to high-prestige posts. Krook and O'Brien (2012) identify three overarching hypotheses explaining patterns in women's presence in (high-prestige and masculine) portfolios: institutional arrangements, women's inclusion among political elites, and broader norms of gender equality. Their work finds strong support for the first two claims, but only limited evidence in favor of the third. Other studies confirm the importance of components of all three hypotheses. Institutional arrangements including the form of government (Bego 2014), specialist cabinet recruitment patterns (Bauer and Okpotor 2013; Claveria 2014; Davis 1997; Siaroff 2000), the ideological commitments of governing parties (Claveria 2014; Escobar-Lemmon and Taylor-Robinson 2005; Moon and Fountain 1997), and a history of competitive elections (Reynolds 1999) are each positively correlated with women's appointment to cabinets. Left governments and democratic states are also more likely to nominate women to high-prestige portfolios (Escobar-Lemmon and Taylor-Robinson 2005; Jacob, Scherpereel, and Adams 2014; Studlar and Moncrief 1999). Beyond these institutional factors, women's inclusion in cabinets is shaped by strategic considerations - including partisan competition (Escobar-Lemmon and Taylor-Robinson 2005) and patronage-based alliances (Arriola and Johnson 2014) - as well as societal-level features related to gender equality. These include economic development (Bego 2014), religious traditions (Reynolds 1999), and a demonstrated commitment to women's inclusion (Jacob, Scherpereel, and Adams 2014; Reynolds 1999).

Across these studies, one of the most consistent findings is that women's involvement in cabinets is highly correlated with women's access to political office more broadly. Women's presence in both the legislature (Claveria 2014; Escobar-Lemmon and Taylor-Robinson 2005; Reynolds 1999; Siaroff 2000) and the governing parties' parliamentary delegations (Studlar and Moncrief 1997) are each associated with the proportion of 
ministerial portfolios held by women, as is the use of gender quotas by the largest governing party (Claveria 2014). The number of female legislators similarly predicts women's ascension to high-prestige posts (Studlar and Moncrief 1999; Escobar-Lemmon and Taylor-Robinson 2005). Women's presence in legislative assemblies clearly affects the supply of, and demand for, female cabinet ministers.

\section{FEMALE LEADERS AND WOMEN'S ACCESS TO MINISTERIAL POSTS}

A growing literature highlights the multitude of institutional and cultural factors affecting women's selection as cabinet ministers. Though this research offers important insights into women's executive branch appointments, it has also largely overlooked a key actor influencing cabinet composition: the party leader. In particular, no study to date systematically evaluates female party leaders' effects on women's ministerial appointments. This scarcity of research reflects men's traditional dominance as party leaders and heads of governments. Until very recently, there were simply too few female prime ministers and coalition party leaders to allow for a broad-based assessment of their influence on cabinets. As the number of female leaders grows, however, it is essential to examine the gendered links between different executive branch posts.

Across political systems, leaders play an important role in determining cabinet composition. In pure presidential systems, the president appoints and dismisses whomever she wishes to her cabinet. In the parliamentary and semipresidential systems studied here, the leader of each party in government also plays a key role in assigning ministerial appointments within his or her party (Dowding and Dumont 2009). Though no two countries or parties are exactly alike - with some delegating a great deal of authority to leaders and others giving more power to the party executive or parliamentary delegation (Andeweg 2014) - the leader is generally one of the most important and influential politicians within her party (Cross and Blais 2012; Pilet and Cross 2014).

Given the importance of the leadership post, there is reason to believe that the presence of female prime ministers and coalition party leaders affects women's ministerial nominations. At the same time, the direction of this influence is unknown. On the one hand, there is a large body of work linking women's descriptive representation across political arenas, and existing studies posit that female heads of government are positively 
associated with women's cabinet appointments (Davis 1997; Jacob, Scherpereel, and Adams 2014). This suggests a letting-down-the-ladder effect, whereby the presence of female prime ministers and party leaders results in women's appointment to (high-prestige) cabinet posts. On the other hand, others find no link between female leaders and women's cabinet appointments (Krook and O'Brien 2012) or argue that the "impact of female prime ministers and presidents [on women's appointment to cabinet] remains idiosyncratic" (Sykes 2014, 698). The opportunities and constraints facing female leaders may in some cases encourage these women to "shut the door behind them," and women's presence in these posts may result in fewer female cabinet appointees. In the following subsections, we develop these two competing sets of hypotheses explaining female leaders' effects on women's cabinet appointments.

\section{Letting Down the Ladder: Female Leaders Promoting Women's Access to Cabinets}

The presence of a female governing party leader may improve women's access to (high-prestige) cabinet portfolios. These leaders may select or advocate on behalf of - women for these posts, and their presence may alter parties' beliefs concerning women's suitability for office. Across many organizations, female leaders are more likely to promote women than their male counterparts. Studies of corporate behavior, for example, find that companies with more women in top management also have a greater proportion of women in lower managerial positions (Kalev, Dobbin, and Kelly 2006). These patterns from the business world are paralleled in the recruitment of candidates for elected office. Just as female partners at large law firms are more likely than men to hire female associates (Gorman 2005), female local party leaders are more apt to recruit female candidates than their male peers (Crowder-Meyer 2013; Niven 1998).

Research linking women's descriptive representation across political posts supports the expectation that female party leaders are likely to promote women's inclusion in politics. Parties with greater numbers of female internal officeholders, for example, are more likely to adopt quota policies for women (Kittilson 2006), and women in leadership posts are more likely than their male counterparts to support measures to advance women in politics (Tremblay and Pelletier 2001). Women's presence on parties' national executive committees also leads to women's increased 
representation in parties' parliamentary delegations (Kittilson 2006), and female local party presidents are more likely to select female candidates for office (Cheng and Tavits 2011). Together, these studies suggest that in parties where leaders dictate cabinet composition, women prime ministers and coalition party leaders may let down the ladder to other female politicians. Even when the party leader plays a more limited formal role in ministerial selection, she may use her significant influence within her organization to advocate on behalf of her fellow female politicians. ${ }^{1}$

In addition to selecting more female ministers, female party leaders may also be associated with women's appointment to high-prestige posts. Bias against outgroup members may lead male party leaders to overlook women for these positions. Niven (1998) argues, for example, that male gatekeepers evaluate men's unique strengths and weaknesses but lump women together and assign female aspirants conventionally feminine traits. This suggests that female leaders may be more apt to evaluate individual women's competency for high-prestige ministries while their male peers only consider whether or not women are generally well suited for these portfolios.

Beyond these direct effects, the presence of female leaders likely indirectly enhances parties' demand for - or at least acceptance of female cabinet appointees. Female leaders have been shown to improve citizens' beliefs about women's capacity to govern (Beaman et al. 2009). The presence of a female prime minister or coalition party leader may thus make citizens more accepting of women in cabinets and lead them to view women's exclusion from power negatively. Female leaders who usher their parties into government may similarly change party elites' attitudes concerning female cabinet appointees, particularly in highprestige positions. Indeed, a woman's very presence in this post indicates that women have cracked the highest glass ceiling within the party and suggests that its members are amenable to women taking on more - and more prestigious - cabinet positions.

1. Though the leader is sometimes highly constrained with respect to ministerial selection - for example, in the Labour Party in New Zealand and Australia (until 2007) - we still expect leaders to influence the initial composition of the cabinet. Even in these cases, moreover, leaders enjoy significant power with respect to assigning portfolios, as well as in cabinet reshuffles and the removal of ministers. At the same time, we also estimated our baseline models using stricter criteria for selecting the governments included in the analysis. Our findings are robust to focusing only on smaller sets of cases, including considering only Western European countries in which the PMdesignate and coalition party leaders are identified as the principal nominators by De Winter (1995, 132; see appendix for results). 
Finally, female leaders may not only influence the selection of female cabinet ministers within their own organizations; their presence may also have spillover effects for other governing parties. Women's initial ascension to prime ministerial and presidential posts appears to shatter the glass ceiling and allows other women to hold these positions (Jalalzai 2013; Jalalzai and Krook 2010). As well as shifting the broader norms and expectations about women's suitability for executive office, women's cabinet appointments may also be subject to contagion effects. Within advanced parliamentary democracies, parties' propensity to select female candidates is influenced by party competition, with larger parties promoting women in response to smaller parties' efforts on this front (Matland and Studlar 1996). Linking "contagion effects" to cabinet appointments, Davis (1997) shows that a party's willingness to nominate women to government depends as much (if not more) on the number of female parliamentarians from outside the party as it does on the proportion of women within the party's parliamentary delegation. The presence of a female party leader may likewise incentivize other coalition members to select more women as ministers - or place women in high-prestige portfolios - in an effort to appear femalefriendly and progressive.

Female politicians' propensity to promote women in politics, combined with their effects on parties' attitudes toward female ministerial appointees, suggests that female leaders may increase women's access to (high-prestige) cabinet posts. This leads to the first set of hypotheses:

$H_{1 a}$ : The presence of a female leader results in more women in cabinets.

$H_{1 b}$ : The presence of a female leader promotes women's appointment to high-prestige portfolios.

Though female leaders may on average be more likely to appoint female ministers - and to select women for high-prestige posts - these gendered effects may not hold across all cabinets. The link between female leaders and the selection of candidates and elected officials is context-dependent (Kunovich and Paxton 2005), and party gatekeepers' sex is sometimes secondary to partisanship and feminist identification in predicting the recruitment of female candidates (Tremblay and Pelletier 2001). There is similarly reason to expect that the link between female leaders and ministers may vary across governments. In particular, the association between female party leaders and women's access to power may be strongest in ideologically left-leaning governments (i.e., cabinets led by socialist or social democratic parties). 
Left parties have long traditions of publicly embracing gender-egalitarian ideologies (Duverger 1955) and historic ties with progressive women's movements (Beckwith 2000). The link between left parties and women's descriptive representation has also been well documented. Within legislatures, these parties tend to be more open to promoting women to prominent political positions (Lovenduski and Randall 1993). Left-party governments are similarly more apt to appoint female cabinet ministers (Escobar-Lemmon and Taylor-Robinson 2005; Moon and Fountain 1997; Reynolds 1999) and to elevate these women to high-prestige and nonfeminine portfolios (Studlar and Moncrief 1999). Just as left parties have traditionally been more receptive to women's descriptive representation, women in these parties are more likely than other politicians to have progressive attitudes on gender equality policies (Lovenduski and Norris 2003) and to self-identify as feminists (Tremblay and Pelletier 2000). Large left parties have also proved more responsive to contagion effects than their nonleft counterparts (Matland and Studlar 1996).

Left parties' traditional support of women's descriptive representation and commitment to gender equality - coupled with their greater propensity to respond to smaller parties' promotion of female candidates - together suggests that the relationship between female party leaders and women's access to cabinets may be more likely to emerge in left governments. Indeed, the female leaders who are best known for actively recruiting women to cabinet positions, including Michelle Bachelet of Chile and Jóhanna Sigurðardóttir in Iceland, are from left parties. These intraparty dynamics offer a second set of letting-down-the-ladder hypotheses:

$\mathrm{H}_{2 \boldsymbol{a}}$ : In left-party governments, the presence of a female party leader results in more women in cabinets.

$H_{2 b}$ : In left-party governments, the presence of a female party leader promotes women's appointment to high-prestige portfolios.

\section{Shutting the Door: Female Leaders Constraining Women's Access to Cabinets}

While some female heads of government promote women to their cabinets, others fail to do so (Bauer and Tremblay 2011; Jalalzai and Krook 2010). Similarly, though women's presence in top management positions is sometimes correlated with the promotion of female 
employees, in other cases women who succeed in male-dominated settings fail to promote junior women (Staines, Tavris, and Jayaratne 1974). In contrast to the letting-down-the-ladder hypotheses, the incentives and constraints facing male and female leaders - coupled with parties' responses to women in leadership - may in fact yield the opposite outcome. The shutting-the-door hypotheses suggest that the presence of a female governing party leader may actually limit women's access to (high-prestige) cabinet portfolios.

Leadership is both sexed and gendered, with the archetypal leader being "male in appearance and gender," as well as "masculine in character traits" (Sjoberg 2014, 73). This is especially true in executive politics, which has historically been conceived of as the most masculine branch of government (Duerst-Lahti 1997; Jalalzai 2013). Even in the modern era, Sykes (2014) argues that executive leadership is often characterized by at least some "measure of masculine attributes" (696), and female leaders find themselves wielding power in "gender-specific environment $[s]$ molded by 'masculinist' norms and expectations" (691). Women's appointment to leadership posts may make them more cognizant of their gender and force them to "learn competence in masculine behaviours and practices, while being constantly reminded of their feminine status" (Pini 2005, 79). Female executives are thus required to develop strategies that demonstrate their strength, determination, and decisiveness (Sykes 2014). Presenting a more masculine image, in turn, allows women to adhere to the "undeclared male rules of the game" (Shvedova 2002, 44-45).

Given the environments in which they operate, it is not surprising that female leaders often choose not to adhere to conventional gender stereotypes when making decisions (Sjoberg 2014). In established democracies, for example, female chief executive and defense ministers increase defense spending and conflict behavior (Koch and Fulton 2011), and female foreign ministers decrease foreign aid spending ( $\mathrm{Lu}$ and Breuning 2014). For a female party leader, cabinet appointments can likewise be used to signal adherence to masculine norms. Championing men for these posts can be a useful strategy for downplaying the leader's sex, while appointing many female ministers - or placing women in high-prestige posts - may actually draw greater attention to her "femaleness."

Beyond the need to present a masculine image, as compared to their male counterparts, female leaders may reap fewer benefits from - and perceive greater costs to - nominating female ministers. Even in 
seemingly identical situations, men and women are faced with different norms and expectations (Crawford 1995). Male leaders can use women's ministerial appointments to satisfy the demands of women within their party and signal progressive and female-friendly ideals to voters. Female leaders using similar strategies, on the other hand, may be accused of "favoritism" and pursuing "identity politics."

Though shutting-the-door effects are broadly applicable, female leaders may be especially disinclined to appoint women to (high-prestige) cabinet posts in parliamentary and semipresidential democracies. In these political systems, the cabinet's continued survival depends on the approval of a legislative majority. Party leaders and their ministers must enjoy the continued confidence of the assembly in order to retain their posts. Within their parties, moreover, leaders must constantly manage prospective challengers who threaten to unseat them from power (Bynander and 't Hart 2007). Selecting a cabinet in these systems thus requires balancing different personalities, ambitions, and policy aims in order to satisfy powerful individuals and factions within the party, cultivate the support of the selectorate, and temper the ambitions of potential opponents (Dowding and Dumont 2009). When men are the principal powerbrokers within political parties, this can result in male-dominated cabinets. The need to appease male copartisans may be especially acute for female leaders, who have shorter tenures in these posts (O'Neill and Steward 2009) and are especially likely to leave office when their parties are losing vote share (O'Brien 2015).

Female leaders may not only feel less able to promote women; the existence of a female-led party may also release parties from any sense of obligation to do so. Female party leaders can serve as "tokens," acting as representatives for, or symbols of, women (Kanter 1977). Their presence may allow parties in government to feel as if women's demands for access to power have been met. Indeed, it is more difficult for women to argue that they are systematically excluded from government posts when a woman holds one of the most important political positions in the country. The presence of a female leader thus provides cover for women's systematic exclusion from both the cabinet and traditionally high-prestige posts.

As compared to their male counterparts, female leaders may encounter greater costs (and fewer benefits) when advocating for women's appointment to cabinets. Their presence may also reduce the pressure for governing parties to advance women's descriptive representation in the executive branch. Together, this suggests that female prime ministers and 
coalition party leaders may be associated with a decrease in the number of women in (high-prestige) cabinet portfolios. Our third set of hypotheses posit:

$H_{3 a}$ : The presence of a female party leader results in fewer women in cabinets.

$H_{3 b}$ : The presence of a female party leader inhibits women's appointment to high-prestige portfolios.

Though many female leaders face constraints in appointing women to their cabinets, these impediments may be more strongly felt by women in nonleft governments (here, cabinets not led by socialists or social democrats). The desire of conservative and Christian democratic parties to maintain the "status quo" and defer to social conventions (Willets 1992), combined with a historic alignment with religious organizations (Betz 1994), encourages these parties to promote traditional gender roles (Lovenduski and Randall 1993). Liberal parties' commitment to individualism and "merit" can likewise lead them to eschew formal measures that promote gender equality (Dahlerup 2007). Nonleft parties in advanced parliamentary democracies have thus historically lagged behind their left counterparts with respect to women's representation. Nonleft governments, for example, have traditionally been less likely to appoint female cabinet ministers and less willing to assign women to high-prestige portfolios.

Among women from nonleft parties, support for efforts to increase women's descriptive representation is also mixed. While in some cases these women have been supportive of efforts to increase women's presence in elected office (Childs and Webb 2012), in others they have been critical of "identity politics," arguing that female voters are not concerned with the sex of their representatives (Schreiber 2008). Some nonleft female leaders may thus feel less personally or ideologically compelled to select female cabinet ministers.

Even if women from nonleft parties would like to let down the ladder, it can be difficult for them to make claims related to gender equality. Jiménez (2009) finds reluctance among some right women to work on gender topics due to the perception that a "defense of women's problems is damaging" (257). Women in nonleft parties may prefer to sideline "women's issues" and appoint men to their cabinets, lest they be perceived as challenging the gendered status quo. Consistent with this argument, Celis and Ezreel (2015) find that across 10 European countries male representatives in right parties are more likely than their female counterparts to speak on behalf of women. 
The absence of an ideological commitment to advancing women's representation, combined with the potentially high costs of doing so, may discourage women in nonleft parties from promoting female cabinet ministers. This leads to our final set of hypotheses:

$\mathrm{H}_{4 a}$ : In nonleft governments, the presence of a female party leader results in fewer women in cabinets.

$\mathrm{H}_{4 b}$ : In nonleft governments, the presence of a female party leader inhibits women's appointment to high-prestige portfolios.

\section{TESTING THE LINK BETWEEN FEMALE LEADERS AND CABINET MEMBERS}

In order to test our competing letting-down-the-ladder and shutting-thedoor hypotheses, we draw on an original dataset of 206 cabinet-level observations nested in 15 states beginning in 1980. The countries Australia, Austria, Canada, Denmark, Finland, Germany, Greece, Iceland, Ireland, the Netherlands, New Zealand, Portugal, Spain, Sweden, and the United Kingdom - were selected because they encompass the set of advanced parliamentary and semipresidential democracies with stable party systems in which the party leader can be clearly identified and serves in government. Here, democracies are identified using the ParlGov (Döring and Manow 2012) and Polity datasets (Marshall and Jaggers 2014), parliamentary and semipresidential systems are selected based on information provided by Cheibub, Gandhi and Vreeland (2010), and advanced industrial states are defined by OECD membership (see appendix for a discussion of case selection).

Though our theoretical framework is broadly applicable, it is especially important to test our hypotheses in advanced parliamentary and semipresidential democracies. Ministers in these systems formulate policy, dictate which bills are introduced to the legislature, and have access to significant perks and patronage. Women's inclusion in these posts is thus especially important. Beyond the significance of the cabinet, these states have also historically served as a model for the rest of the world with respect to women's representation. Political parties in these countries have been at the forefront of efforts to bolster women's presence in politics, and the first parity cabinets emerged from these governments. When judged by the United Nations Development Programme's gender inequality index, these states are also among 
the most gender equal in the world, and their citizens are largely supportive of women's equality (Inglehart and Norris 2003). If shuttingthe-door effects emerge even in the "easy" case of advanced parliamentary democracies, biases against women may also remain entrenched elsewhere.

Beyond these theoretical justifications, there are also empirical reasons to study this set of countries. These states provide sufficient variation in women's presence in executive office to test our hypotheses while at the same time allowing us to hold constant a broader set of political, socioeconomic, and cultural variables. Focusing on these countries thus allows us to minimize variation on a number of societal-level intervening factors while still making more generalizable claims. Finally, we begin our analysis in 1980, as before 1979 there were no female-led governing parties in our dataset.

\section{Measuring and Modeling Women's Appointment to Cabinets and Access to High-Prestige Posts}

To establish whether female party leaders let down the ladder or shut the door behind them, we consider two measures of women's access to cabinets. First, we examine the percentage of female cabinet ministers. Second, we analyze women's appointment to high-prestige posts from which they have historically been excluded (Krook and O'Brien 2012). ${ }^{2}$ To do so, we determine whether a woman held the finance, foreign affairs, interior/home affairs, ${ }^{3}$ or defense ministries during each government. Though the meaning and significance assigned to individual portfolios

2. A related question concerns female leaders' effects on women's access to medium- and low-prestige positions. In contrast to high-prestige posts - which generate straightforward empirical expectations the link between leaders' sex and these portfolios is more nuanced. With respect to the letting-down-theladder effect, for example, we might posit a negative relationship between female leaders and women's inclusion in low-prestige posts because female leaders break down gender stereotypes and advocate for women's appointment to more desirable positions. At the same time, cabinets with female leaders may have more women in these portfolios because female leaders may appoint more female ministers across the board. The same can be said of medium- and low-prestige positions and the shutting-the-door effect. The study of female leaders and women's access to medium- and low-prestige positions - as well as masculine and feminine posts - deserves further study in work that fully theorizes these relationships. At the same time, though beyond the scope of this paper, we fit preliminary models predicting women's presence in medium-/low-prestige portfolios (see Models Al6-Al8 in the appendix). There is no significant link between female prime ministers and women's appointment to these positions. However, the presence of any female leader is correlated with women's decreased access to these posts. Indeed, women hold the largest number of medium- and low-prestige portfolios in left cabinets with all male leaders.

3. In the absence of an interior or home affairs portfolio, we sought out an equivalent post: for Sweden, the labor/employment ministry; for Australia and New Zealand, the justice ministry; for Canada, the 
varies over time and space (Bauer and Tremblay 2011), these four posts are consistently identified as high-prestige appointments in existing studies of women in cabinets (Escobar-Lemmon and Taylor-Robinson 2005, 2009; Krook and O'Brien 2012; Reynolds 1999). The foreign affairs, interior, and finance posts are also generally viewed as the most important ministries in Western European cabinets (Druckman and Warwick 2005). ${ }^{4}$ Historical evidence further supports the argument that these positions represent important appointments from which women have traditionally been excluded. Among the countries studied, the first female foreign affairs minister was not selected until 1976 (Sweden's Karin Söder). Similarly, the first women to serve as finance and defense ministers were New Zealand's Ruth Richardson and Canada's Kim Campbell, appointed in 1990 and 1993, respectively.

While our sample of cabinets is taken from the ParlGov database (Döring and Manow 2012), we constructed the measures of both the proportion of women in cabinets and women's access to high-prestige posts, relying primarily on the Keesing's World News Archive. As a governing party's leader typically holds a ministerial portfolio, we remove both male and female party leaders from the counts of male and female ministers. ${ }^{5}$ Excluding leaders from our dependent variables allows us to determine whether women in these posts are likely to promote other women to cabinets. Additionally, we exclude the cases in which a female leader takes a high-prestige post for herself, as this does not reflect her (un)willingness to appoint other women to these portfolios.

ministry of public safety and solicitor general; for Iceland, the ministry of justice and ecclesiastical affairs.

4. Our results are robust to excluding the defense ministry from our measure of "high-prestige" portfolios (see Models $\mathrm{Al} 3$ through $\mathrm{Al} 5$ in the appendix).

5. Take, for example, Wolfgang Schüssel's first ÖVP-FPÖ coalition in Austria. Including the chancellor, there were 12 cabinet members, 4 of whom were women. One of these women was FPÖ leader Susanne Riess-Passer, who served as vice chancellor. As we seek to determine whether the party leaders' sex affects the nomination of other women to cabinets, we exclude all party leaders from our dependent variable. Removing both Schüssel and Riess-Passer, we are left with seven men and three women. As the leaders are represented in the cabinet, their inclusion in the outcome variable would artificially inflate female leaders' appointment of female ministers (and similarly deflate male leaders' appointment of women). Excluding leaders from the dependent variable is thus necessary to accurately test the link between leaders' sex and the gender composition of the cabinet. At the same time, the inclusion or exclusion of party leaders generates small differences in the measure of women's inclusion. In the ÖVP-FPÖ case, for example, with the leaders the cabinet is $33 \%$ female, while without it is $30 \%$ female. As compared to the variation across cabinets within the same country, however, these differences are very minor and accurately reflect women's presence in the posts not reserved for/captured by party leaders. 
Finally, the empirical analyses assess both women's presence in cabinets and access to high-prestige posts using logistic regression models with country-level random effects. These varying-intercept random effects account for the covariance between cabinets within a given country and capture baseline differences in their propensities to select female ministers and/or appoint them to high-prestige portfolios.

\section{Measuring the Presence of Female Leaders}

Female leaders may promote or inhibit women's access to cabinets. To test the hypotheses about female leaders alone $\left(\boldsymbol{H}_{1}\right.$ and $\left.\boldsymbol{H}_{3}\right)$, we drew on an original dataset of party leaders to create two measures. We focus first on female prime ministers. Across the governments in our study, there are 18 female-headed cabinets. These include the governments of Julia Gillard in Australia, Kim Campbell in Canada, Helle Thorning-Schmidt in Denmark, Anneli Jäätteenmäki and Mari Kiviniemi in Finland, Angela Merkel in Germany, Jóhanna Sigurðardóttir in Iceland, Jenny Shipley and Helen Clark in New Zealand, and Margaret Thatcher in the United Kingdom. We then broaden our analysis to distinguish between governments with any female-led party and those comprised exclusively of male-led organizations. There are 32 cabinets in which at least one (major or minor) party was female-led, and four in which women headed two of these parties. In the exceptional case described above - the Danish coalition government formed in 2012 - women led all three governing parties. In total, 37 cabinets (18\% of all observations) contain at least one female-led party.

The second and fourth sets of hypotheses $\left(\boldsymbol{H}_{2}\right.$ and $\left.\boldsymbol{H}_{4}\right)$ address not just the party leader's sex, but also the differing incentives faced by leaders from left and nonleft parties. To capture this relationship, we include an interaction effect between government ideology and presence of a female leader. As a measure of ideology, we use the prime minister's party family as reported by the ParlGov database. We distinguish left governments - cabinets in which the prime minister is from a socialist or social democratic party - from nonleft governments in which she is from a conservative, Christian democratic, liberal, or agrarian party. In total, we have four cabinet types: 15 female-led left cabinets; 22 femaleled nonleft cabinets; 65 male-only left cabinets; and 104 male-only nonleft cabinets. 


\section{Controlling for Alternative Explanations}

Beyond the main predictors, we control for factors that may otherwise bias the results. Over time parties may become more likely to appoint women to executive office. We thus include three time period dummy variables. The models also have a covariate capturing the percentage of seats held by women in parliament, as increasing the number of female legislators can alter both the supply of — and demand for - female leaders and women in cabinets. Existing research likewise suggests that female ministers are more common in specialist than generalist systems, so we account for specialist systems using data from Siaroff (2000). Similarly, we control for the number of parties in government, as female leaders are more likely to be present in coalitions, and these governments face distinct incentives as compared to those that do not share cabinet posts (Krook and O'Brien 2012). Since federal systems have been shown to positively affect women's descriptive representation (Stockemer and Tremblay 2015), we also capture the degree of federalism in the country using data from the Comparative Political Data Set I (1960-2012).

\section{RESULTS}

Table 1 presents the findings from six logistic regression analyses, each examining the relationship between female leaders and ministers across 15 parliamentary and semipresidential democracies. Taken together, a clear picture emerges from these results: female leaders do not let down the ladder to other women, and in some cases shut the door behind them. Female prime ministers and minor party leaders have fewer women in their cabinets than their male counterparts, and women are no more likely to hold high-prestige posts in female-led governments.

\section{Female Party Leaders and Women's Presence in Cabinets}

There is tremendous variation in women's representation across cabinets. Some governments, particularly in the early period, included no women. Among the cabinets formed in the 1980s, for example, there were 14 allmale governments. By the 1990s, a norm of including at least one female minister had been established. The last all-male government in these countries was the 1990 cabinet formed by British Conservative John Major. Even after the establishment of an inclusion norm, 
Table 1. Random effects logit models of women in cabinets (standard errors in parentheses)

\begin{tabular}{|c|c|c|c|c|c|c|}
\hline & \multicolumn{3}{|c|}{$\%$ Fem. Cabinet Minister } & \multicolumn{3}{|c|}{ Fem. Min. in High-Prestige Post } \\
\hline & Model 1 & Model 2 & Model 3 & Model 4 & Model 5 & Model 6 \\
\hline Intercept & $-3.505(0.182)$ & $-3.575(0.191)$ & $-3.214(0.170)$ & $-3.424(0.799)$ & $-3.300(0.815)$ & $-3.013(0.808)$ \\
\hline Fem. prime minister & $-0.311(0.164)$ & & & $-1.011(0.699)$ & & \\
\hline Fem. party leader & & $-0.258(0.131)$ & & & $-0.054(0.494)$ & \\
\hline Fem. party leader $\times$ left party & & & $-0.545(0.192)$ & & & $-0.293(0.836)$ \\
\hline Fem. party leader $\times$ right party & & & $-0.551(0.177)$ & & & $-0.270(0.672)$ \\
\hline Male party leader $\times$ right party & & & $-0.457(0.121)$ & & & $-0.350(0.514)$ \\
\hline $1990 \mathrm{~s}$ & $0.293(0.144)$ & $0.319(0.145)$ & $0.329(0.142)$ & $0.572(0.581)$ & $0.623(0.586)$ & $0.626(0.583)$ \\
\hline $2000 s$ & $0.457(0.155)$ & $0.465(0.156)$ & $0.443(0.148)$ & $0.835(0.641)$ & $0.831(0.653)$ & $0.812(0.651)$ \\
\hline$\%$ fem MP & $0.064(0.007)$ & $0.066(0.007)$ & $0.069(0.006)$ & $0.099(0.030)$ & $0.091(0.031)$ & $0.093(0.031)$ \\
\hline \# of parties & $0.051(0.055)$ & $0.073(0.057)$ & $0.092(0.052)$ & $-0.078(0.230)$ & $-0.092(0.235)$ & $-0.084(0.234)$ \\
\hline Specialist Cabinet & $-0.013(0.127)$ & $-0.034(0.129)$ & $-0.138(0.124)$ & $-0.811(0.633)$ & $-0.654(0.654)$ & $-0.722(0.669)$ \\
\hline Left cabinet & $0.335(0.104)$ & $0.336(0.104)$ & & $0.341(0.413)$ & $0.238(0.408)$ & \\
\hline Strong federalism & $0.356(0.147)$ & $0.367(0.147)$ & $0.435(0.128)$ & $-0.502(0.757)$ & $-0.603(0.778)$ & $-0.568(0.769)$ \\
\hline Weak federalism & $0.001(0.165)$ & $0.011(0.163)$ & $0.015(0.146)$ & $0.074(0.767)$ & $0.040(0.801)$ & $0.038(0.779)$ \\
\hline Country-level std. dev. & 0.009 & 0.008 & 0.000 & 0.481 & 0.562 & 0.511 \\
\hline
\end{tabular}

Notes: The outcome variable in Models 1,2, and 3 is the percentage of ministerial portfolios held by women. The outcome variable in Models 4,5, and 6 is a dichotomous measure of women's appointment to at least one of the four high-prestige posts. Number of observations: 206 cabinets; number of groups: 15 countries. 
however, women's representation still varies greatly. On one end of the spectrum are governments like that formed by Antonis Samaras in Greece in 2012. His cabinet had only one female minister, Olga Kefalogianni, holding the tourism portfolio. On the other are governments like the Finnish center-right/green coalition government formed in 2007. Led by Matti Vanhanen, 12 of the 20 total ministerial posts were held by women. After removing the (three male and one female) party leaders in the cabinet, 11 of the 16 available positions $(69 \%)$ were allocated to women.

Looking across the three logistic regression models of women's presence in cabinets shown in Table 1 , the link between female party leaders and women's portfolio allocation becomes clear. In each case the presence of a female leader is significantly and negatively associated with women's nomination to office. Lending support to the shutting-the-door hypothesis $\left(\boldsymbol{H}_{3 \mathbf{a}}\right)$, Model 1 finds that female prime ministers are less likely to include women in their cabinets. While the predicted proportion of posts held by female appointees is $17 \%$ with a male head of government, it drops to $13 \%$ with a woman in this post. ${ }^{6}$ This result holds when also considering coalition party leaders (Model 2). In this case, the predicted percentage of seats decreases from $17 \%$ in exclusively male-led cabinets to $14 \%$ in governments with at least one female-led party.

To test the claim that women in left governments are more likely to let down the ladder $\left(\boldsymbol{H}_{2 \boldsymbol{a}}\right)$ - and that those in nonleft cabinets may shut the door $\left(\boldsymbol{H}_{4 \boldsymbol{a}}\right)$ - Model 3 includes an interaction effect between government ideology and the presence of a female leader. The results suggest that ideology interacts with leaders' sex to shape cabinet appointments, but not as predicted. Rather than women on the left letting down the ladder, male-dominated left governments are significantly more likely to allocate portfolios to female ministers than any other cabinet type. The predicted proportion of female cabinet appointees is $22 \%$ in male-only left governments. This figure drops to $14 \%$ in male-only nonleft governments and $15 \%$ and $14 \%$, respectively, in left and nonleft governments with at least one female leader. There are no significant differences between exclusively male nonleft cabinets and either female left or nonleft governments, but all three nominate significantly fewer women as ministers than male-dominated left executives.

6. All predicted values are generated holding other variables at their median or modal values and are significant at the $\alpha=0.1$ level. 
These results from our cross-national analyses are not only consistent with the shutting-the-door hypothesis $\left(\boldsymbol{H}_{\mathbf{3} \boldsymbol{a}}\right)$, but also with the behavior of male and female party leaders across advanced parliamentary democracies. Both popular and scholarly works frequently point to Margaret Thatcher as the quintessential example of a woman shutting the door behind her. During her 11 years as British prime minister, Thatcher selected only one woman for her cabinet. Janet Young was the leader of the House of Lords from 1981 to 1983 , lasting for only two years in her position before being relegated to a junior ministerial post. While by far the most frequently cited example of this phenomenon, Thatcher is not alone in her decision to appoint a nearly all-male cabinet. In the two years she governed New Zealand, Jenny Shipley's cabinets had only one female minister.

Just as there are examples of governments with female-led parties appointing fewer women to cabinets, there are also cases that illustrate the propensity of left male leaders to allocate portfolios to women. Indeed, the notion of a "parity cabinet" has its roots in Swedish Social Democratic Prime Minister Ingvar Carlsson’s 1994 government, in which half of all members were women. Other male prime ministers have followed Carlsson's example, including Spain's José Zapatero. After the 2008 election, the socialist leader appointed nine women and eight men to his government.

\section{Female Party Leaders and Women's Appointment to High-Prestige Posts}

Of the four high-prestige positions, women in advanced parliamentary democracies have the greatest access to interior or home affairs portfolios (40 cabinets), followed by foreign affairs ministries (22 cabinets). They remain almost wholly excluded from defense (10 cabinets) and finance (8 cabinets) posts. Though the majority of governments fail to appoint female ministers to any of these positions (146 cabinets, or $71 \%$ of observations), women have arguably made major inroads in these traditionally male-dominated appointments. Over one-fifth of cabinets (44 in total) include women in at least one high-prestige post. Another 8\% (16 cabinets) have appointed women to two or more of these portfolios. The vast majority of these appointments, moreover, have occurred since 2000.

While women's presence in high-prestige posts has increased dramatically in the past 15 years, this growth cannot be attributed to 
female leaders letting down the ladder. To the contrary, as shown in Table 1, female leaders are no more likely than their male counterparts to appoint women to these portfolios. Indeed, there are no circumstances in which women's presence in leadership consistently facilitates female ministers' access to high-prestige positions. Neither female prime ministers in particular (Model 4), nor the presence of a female leader more broadly (Model 5), is associated with women's access to these ministries. Even in left governments (Model 6), the presence of a female leader is not correlated with women's nomination to these posts. Additional analyses further suggest that female leaders are neither more likely to first appoint women to high-prestige portfolios, nor to include women in these positions after the glass ceiling has already been shattered (see Models A19-A26 in the appendix). ${ }^{7}$

These results are once again consistent with the experiences of female cabinet appointees across advanced industrialized democracies. Women are excluded from all conventionally high-prestige posts in the majority of cabinets with female prime ministers or coalition party leaders. This trend, moreover, is not limited to nonleft parties. Just as Margaret Thatcher did not select women for these positions, Social Democratic Danish Prime Minister Helle Thorning-Schmidt's cabinet did not include female ministers in these portfolios. Nonetheless, there are five instances (out of 18 cases) in which female prime ministers appoint women to high-prestige posts. The most "woman-friendly" femaleheaded cabinet was the second government of Jóhanna Sigurðardóttir, in which women held two of these portfolios. These female ministers did not serve contemporaneously, however, and Oddný Harðardóttir only became finance minister during Sigurðardóttir's final 18 months in office.

As with female-led governments, a majority of male-dominated cabinets also fail to appoint women to high-prestige ministries. Yet, across the cases studied there are 55 examples (of 188 cabinets) of male prime ministers allocating at least one of these portfolios to women. An additional 14

7. We had also hoped to include a variable controlling for female prime ministers' and coalition party leaders' prior service in high-prestige ministries in order to determine whether female leaders' experience in these portfolios influenced their willingness to appoint women to these posts. Of the 23 female leaders in our dataset, only one of these women had previously held a high-prestige position: Canada's Kim Campbell acted as Minister of National Defence before becoming head of government. When female leaders had previously served in cabinet, they often occupied posts that are more traditionally associated with women. With only Campbell holding a high-prestige portfolio, we did not have sufficient information to test this particular hypothesis. At the same time, this suggests that male and female leaders may have distinct - and indeed gendered - pathways to power. Though beyond the scope of this paper, we hope to take up this question in future studies. 
male-led governments nominated female ministers to two of these posts. These include both governments with socialist and social democratic prime ministers - such as those of Alfred Gusenbauer and Werner Faymann in Austria and Göran Persson in Sweden - and right-leaning cabinets, like those led by José Manuel Barroso in Portugal and Brian Mulroney in Canada. In the highest-profile case of a male prime minister appointing women to traditionally high-prestige positions, Zapatero's parity cabinet included Elena Salgado as Minister of Economy and Finance, Trinidad Jiménez as Minister of Foreign Affairs and Cooperation, and Carme Chacón as Minister of Defence. Chacón's appointment in particular garnered a great deal of attention, as she was seven months pregnant when she assumed the post. The dissonance between her ultrafeminine appearance and high-prestige, "masculine" appointment led to worldwide media coverage of her nomination.

\section{DISCUSSION}

The presence of a female prime minister - or even a female-led coalition party - is associated with fewer women in cabinets, particularly as compared to exclusively male-led left governments. Female-led cabinets, moreover, are no more likely to appoint women to high-prestige posts than male-dominated governments. While these results are initially counterintuitive in light of the large body of work suggesting that female politicians will promote other women, they are consistent with recent political developments across advanced parliamentary democracies. Female prime ministers in these states have not made high-profile commitments to parity cabinets. Rather, it is male leaders on the left who are making these pledges, including, most recently, Italy's Matteo Renzi. These men have been roundly praised for their inclusive governments and are often heralded as being progressive and femalefriendly leaders. Conversely, their male counterparts who have excluded women - like David Cameron in the UK and Tony Abbott in Australia - were criticized for failing to select greater numbers of female ministers.

Though male leaders can reap significant benefits from appointing women to their cabinets - and encounter some costs for failing to do so - it is not clear that female leaders face similar incentives. In the parliamentary and semipresidential systems studied here, party leaders always run the risk of being removed from their post (and thus their position in cabinet). Female leaders may feel especially susceptible to 
male challengers, and therefore cultivate loyalty by appointing these men to government posts. As the face of their party, moreover, these women need to be especially conscientious of how their actions will be portrayed in the media and perceived by voters. Appointing too many female ministers - or placing them in high-prestige posts - may be interpreted not as progressive, but rather as favoritism or identity politics. Indeed, while leaders like Zapatero, Renzi, and France's François Hollande were commended for their parity cabinets, when Acting Party Leader Harriet Harman pushed for parity in the British Labour Party's shadow cabinet, she received much less praise. Clearly, seemingly identical actions are likely to be perceived differently depending on the sex of the leader. Due to the constraints placed on women in these posts, in some cases it may be easier for male politicians to shift norms about women's inclusion in high-level politics. Given the limits inherent in statistical analyses based on observational data, future work should explore the motivations underlying the cabinet appointments of both male and female leaders.

While the presence of a female leader does not necessarily promote women's access to cabinets in parliamentary and semipresidential democracies, female heads of government may behave differently in pure presidential regimes. In presidential systems, the executive is neither drawn from, nor accountable to, the legislature. This separation of survival - as well as the president's position as formateur, independent control over cabinet appointments, personal mandate, term limits, and greater individual authority to implement her goals - together create different preferences and prerogatives vis-à-vis ministerial appointments (Amorim Neto and Samuels 2010; Weller 2014). Presidents, for example, are both more likely than prime ministers to select nonpartisan ministers (Amorim Neto and Samuels 2010) and also less likely to allocate cabinet portfolios proportionally (Amorim Neto 2006).

As presidents are often (though not always) less constrained than their parliamentary counterparts, there is reason to suspect that leaders' sex has different effects across regime types (Reyes-Housholder 2013). ${ }^{8}$ Anecdotal evidence suggests that female presidents (particularly from left parties) may be especially willing to nominate female ministers. Brazil's Dilma Rousseff, Costa Rica's Laura Chinchilla, and Michelle Bachelet of Chile

8. These differing incentives and opportunities may help to explain Krook and O'Brien's (2012) finding that leader's sex is unrelated to their Gender Power Score. If the effect of gender works differently across regime types - with female leaders in presidential systems promoting women and those in parliamentary systems feeling constrained on this front - these countervailing tendencies may together generate a null result. 
each appointed record-breaking numbers of women to their cabinets. In Liberia, Ellen Johnson Sirleaf went as far as to publically state, "If I had my way, I would have had an all-woman cabinet." At the same time, even in presidential systems, not all female leaders champion women. Argentina's Cristina Fernández de Kirchner maintained the gender status quo, and South Korea's Park Geun-hye nominated fewer women to her cabinet than her male predecessor. Building on our findings, future work should assess when female presidents have the incentives and capacity to let down the ladder to female cabinet appointees, and when they shut the door behind them.

\section{CONCLUSIONS}

Rather than letting down the ladder and bringing women into their cabinets, female leaders in advanced parliamentary democracies sometimes shut the door behind them. Looking across 206 cabinets in 15 countries from 1980 to the present, we show that the presence of either a female prime minister or a female-led coalition party is associated with fewer female ministers, particularly as compared to exclusively male-led left governments. Cabinets with female prime ministers or coalition party leaders, moreover, are no more likely to appoint women to high-prestige posts than their male-dominated counterparts.

These findings have important consequences for the study of both women in the executive and women's representation more broadly. At the most basic level, we highlight an important (and largely overlooked) factor explaining women's access to ministerial portfolios. As the number of female leaders increases over time, research on cabinets will need to account for their role in advancing or hindering women's nomination to these posts. Our results further illustrate that we cannot assume that women's presence in one political arena will uniformly lead to women's inclusion elsewhere. To the contrary, different forms of descriptive representation are sometimes in tension with one another. We thus need careful theorizing about when and why women's increased presence in one area is likely to promote, or inhibit, women's access to other positions.

The growing number of female leaders also demands a new body of scholarship examining how women and men behave once in office. Building on our findings, researchers should consider whether female leaders' pathways to power influence their propensity to advance women's descriptive and substantive representation. In addition to 
comparing presidents and prime ministers, more scholarship is needed to understand the effects of intraparty leadership selection mechanisms. Female leaders chosen by the parliamentary party may behave differently than those elected by the party membership more broadly. Likewise, future work should consider the interaction between the expectations placed on leaders because of their sex and the gendered nature of the position itself. A growing body of evidence suggests that the post of head of government can be more or less masculine in different times and places (Jalalzai 2011; Sykes 2013). Comparing women in highly masculine posts to both men and women in less masculine environments would provide significant insights into leaders' behavior. This new body of research will demand both quantitative medium- and large-N studies and careful qualitative assessments of individual leaders' aims and motivations.

Finally, though we find some support for the shutting-the-door hypotheses, our results do not imply that gender equality advocates should eschew female prospective leaders in favor of their male counterparts. Female party leaders have been linked to a number of other outcomes that are beneficial for women, including the selection of greater numbers of female candidates (Cheng and Tavits 2011) and positive shifts in societal attitudes toward gender equality more broadly (Beaman et al. 2012). Even in the absence of these knock-on effects, women's ascension to these positions serves as an important marker of gender equality. Indeed, we will not have reached parity in politics until women are as likely as men to be selected for these posts. Rather than promoting the selection of male leaders, our findings demonstrate the need for a shift in the norms concerning women's representation in executive politics. Parity cabinets must become the standard, such that all leaders (irrespective of their sex) are expected to appoint equal numbers of men and women. Until that time, scholars and activists alike must be cognizant of the unique challenges facing - and distinct opportunities available to - female leaders.

Diana Z. O'Brien is Assistant Professor of Political Science at Indiana University, Bloomington, IN: dzobrien@indiana.edu; Matthew Mendez is a lecturer in Political Science at Pomona College, Claremont, CA: mmcy2015@pomona.edu; Jordan Carr Peterson is a graduate student in Political Science and International Relations at the University of Southern California, Los Angeles, CA: jordancp@usc.edu; Jihyun Shin is a graduate student in Political Science and International Relations at the University of Southern California, Los Angeles, CA: jihyunsh@usc.edu 


\section{REFERENCES}

Amorim Neto, Octavio. 2006. "The Presidential Calculus: Executive Policy Making and Cabinet Formation in the Americas." Comparative Political Studies 39 (4): 415-40.

Amorim Neto, Octavio, and David Samuels. 2010. "Democratic Regimes and Cabinet Politics: A Global Perspective." Revista Ibero-Americana de Estudios Legislativos 1 (1): $10-23$.

Andeweg, Rudy B. 2014. "Cabinet Ministers: Leaders, Team Players, Followers?” In The Oxford Handbook of Political Leadership, ed. Paul 't Hart and R. A. W. Rhodes (ed.),. Oxford: Oxford University Press, 532-46.

Arriola, Leonardo R., and Martha C. Johnson. 2014. "Ethnic Politics and Women's Empowerment in Africa: Ministerial Appointments to Executive Cabinets." American Journal of Political Science 58 (2): 495-510.

Atchison, Amy, and Ian Downs. 2009. "Women Cabinet Ministers and Female-Friendly Social Policy." Poverty \& Public Policy 1 (2): 1-23.

Barnes, Tiffany D., and Diana Z. O'Brien. 2015. "Defending the Realm: The Appointment of Female Defense Ministers Worldwide." Presented at the $4^{\text {th }}$ European Conference on Politics and Gender, Uppsala, Sweden.

Bauer, Gretchen, and Faith Okpotor. 2013. “Her Excellency”: An Exploratory Overview of Women Cabinet Ministers in Africa. Africa Today 60 (1): 76-97.

Bauer, Gretchen, and Manon Tremblay, eds. 2011. Women in Executives: A Global Overview. London: Routledge.

Beaman, Lori, Raghabendra Chattopadhyay, Esther Dulfo, Rohini Pande, and Petia Topalova. 2009. "Powerful Women: Does Exposure Reduce Bias?" The Quarterly Journal of Economics 124 (4): 1497-540.

Beaman, Lori, Esther Duflo, Rohini Pande, and Petra Topalova. 2012. "Female Leadership Raises Aspirations and Educational Attainment for Girls: A Policy Experiment in India." Science 335 (6068): 582-86.

Beckwith, Karen. 2000. "Beyond Compare? Women's Movements in Comparative Perspective." European Journal of Political Research 37 (4): 431-68.

Bego, Ingrid. 2014. "Accessing Power in New Democracies: The Appointment of Female Ministers in Postcommunist Europe.” Political Research Quarterly 67 (2): 347-60.

Betz, Hans-Georg. 1994. Radical Right-Wing Populism in Western Europe. Basingstoke: Macmillan.

Borrelli, MaryAnne. 2002. The President's Cabinet. Boulder: Lynne Rienner.

Bynander, Fredrik, and Paul 't Hart. 2007. "The Politics of Party Leadership Survival and Succession: Australia in Comparative Perspective." Australian Journal of Political Science 42 (1): 47-72.

Celis, Karen, and Silvia Erzeel. 2015. "Beyond the Usual Suspects: Non-Left, Male and Non-Feminist MPs and the Substantive Representation of Women." Government and Opposition 50 (1): 45-64.

Cheibub, José Antonio, Jennifer Gandhi, and James Raymond Vreeland. 2010. "Democracy and Dictatorship Revisited." Public Choice 143 (1-2): 67-101.

Cheng, Christine, and Margit Tavits. 2011. "Informal Influences in Selecting Female Political Candidates." Political Research Quarterly 64 (2): 460-71.

Childs, Sarah, and Paul Webb. 2012. Sex, Gender and the Conservative Party: From Iron Lady to Kitten Heels. Basingstoke: Palgrave Macmillan.

Claveria, Sílvia. 2014. “Still a 'Male Business'? Explaining Women’s Presence in Executive Office." West European Politics 37 (5): 1156-76.

Crawford, Mary. 1995. Talking Difference: On Gender and Language. London: Sage. 
Cross, William P., and André Blais. 2012. Politics at the Centre: The Selection and Removal of Party Leaders in the Anglo Parliamentary Democracies. New York: Oxford University Press.

Crowder-Meyer, Melody. 2013. “Gendered Recruitment without Trying: How Local Party Recruiters Affect Women's Representation.” Politics \& Gender 9 (4): 390-413.

Dahlerup, Drude. 2007. "Electoral Gender Quotas: Between Equality of Opportunity and Equality of Result.” Representation 43 (2): 73-92.

Davis, Rebecca Howard. 1997. Women and Power in Parliamentary Democracies: Cabinet Appointments in Western Europe, 1968-1992. Lincoln: University of Nebraska Press.

De Winter, Lieven. 1995. "The Role of Parliament in Government Formation and Resignation." In Parliaments and Majority Rule in Western Europe, ed. Herbert Döring. New York: St. Martin's Press, 115-51.

Döring, Holger, and Philip Manow. 2012. Parliament and Government Composition Database (ParlGov). Version 12/10-15 October 2012.

Dowding, Keith, and Patrick Dumont. 2009. "Structural and Strategic Factors Affecting the Hiring and Firing of Ministers." In The Selection of Ministers in Europe: Hiring and Firing, ed. Keith Dowding and Patrick Dumont. London: Routledge, 1-20.

Druckman, James N., and Paul V. Warwick. 2005. "The Missing Piece: Measuring Portfolio Salience in Western European Parliamentary Democracies." European Journal of Political Research 44 (1): 17-42.

Duerst-Lahti, Georgia. 1997. "Reconceiving Theories of Power." In The Other Elites, ed. Mary Anne Borrelli and Janet M. Martin. Boulder, CO: Lynne Rienner, 11-32.

Duverger, Maurice. 1955. The Political Role of Women. Paris: UNESCO.

Escobar-Lemmon, Maria, and Michelle M. Taylor-Robinson. 2005. "Women Ministers in Latin American Government." American Journal of Political Science 49 (4): 829-44.

- 2009. "Getting to the Top: Career Paths of Women in Latin American Cabinets." Political Research Quarterly 62 (4): 685-99.

Gorman, Elizabeth H. 2005. "Gender Stereotypes, Same-Gender Preferences, and Organizational Variation in the Hiring of Women: Evidence from Law Firms." American Sociological Review 70 (4): 702-28.

Inglehart, Ronald, and Pippa Norris. 2003. Rising Tide: Gender Equality and Cultural Change Around the World. New York: Cambridge University Press.

Jacob, Suraj, John A. Scherpereel, and Melinda Adams. 2014. "Gender Norms and Women's Political Representation: A Global Analysis of Cabinets, 1979-2009." Governance 27 (2): $321-45$.

Jalalzai, Farida. 2011. "A Critical Departure for Women Executives or More of the Same? The Powers of Chancellor Merkel." German Politics 20 (3): 428-48.

- 2013. Shattered, Cracked, or Firmly Intact? Women and the Executive Glass Ceiling Worldwide. New York: Oxford University Press.

Jalalzai, Farida, and Mona Lena Krook. 2010. "Beyond Hillary and Benazir: Women's Political Leadership Worldwide." International Political Science Review 31 (1): 5-21.

Jiménez, Antonia M. Ruiz. 2009. "Women and Decision-Making Participation within Rightist Parties in Portugal and Spain." Análise Social 44 (191): 235-63.

Kalev, Alexandra, Frank Dobbin, and Erin Kelly. 2006. "Best Practices or Best Guesses? Assessing the Efficacy of Corporate Affirmative Action and Diversity Policies." American Sociological Review 71 (4): 589-617.

Kanter, Rosabeth Moss. 1977. "Some Effects of Proportions on Group Life: Skewed Sex Ratios and Responses to Token Women." American Journal of Sociology 82 (5): 965-90.

Kittilson, Miki Caul. 2006. Challenging Parties, Changing Parliaments: Women and Elected Office in Contemporary Western Europe. Columbus: Ohio State University Press. 
Koch, Michael T., and Sarah A. Fulton. 2011. "In the Defense of Women: Gender, Office Holding and National Security Policy in Established Democracies." Journal of Politics $73(1): 1-16$.

Krook, Mona Lena, and Diana Z. O’Brien. 2012. “All the President's Men? The Numbers and Portfolio Allocations of Female Cabinet Ministers." Journal of Politics 74 (3): 840_ 55.

Kunovich, Sheri, and Pamela Paxton. 2005. "Pathways to Power: The Role of Political Parties in Women's National Political Representation.” American Journal of Sociology 111 (2): 505-52.

Laver, Michael, and Kenneth A. Shepsle. 1994. Cabinet Ministers and Parliamentary Government. New York: Cambridge University Press.

Lovenduski, Joni, and Vicky Randall. 1993. Contemporary Feminist Politics: Women and Power in Britain. New York: Oxford University Press.

Lu, Kelan, and Marijke Breuning. 2014. "Gender and Generosity: Does Women's Representation Affect Development Cooperation?" Politics, Groups, and Identities $2(3): 313-30$.

Marshall, Monty G., and Keither Jaggers. 2014. "Polity IV Annual Time-Series, 18002013.” http://www.systemicpeace.org/inscrdata.html (accessed March 8, 2014).

Matland, Richard E., and Donley T. Studlar. 1996. "The Contagion of Women Candidates in Single-Member District and Proportional Representation Electoral Systems: Canada and Norway." Journal of Politics 58 (3): 707-33.

Moon, Jeremy, and Imogen Fountain. 1997. "Keeping the Gates? Women as Ministers in Australia, 1970-96." Australian Journal of Political Science 32 (3): 455-66.

Murray, Rainbow. 2010. Cracking the Highest Glass Ceiling: A Global Comparison of Women's Campaigns for Executive Office. Santa Barbara, CA: Praeger Publishers.

Niven, David. 1998. "Party Elites and Women Candidates: The Shape of Bias." Women \& Politics 19 (2): 57-80.

O'Brien, Diana Z. 2015. "Rising to the Top: Gender, Political Performance, and Party Leadership in Parliamentary Democracies." American Journal of Political Science 59 (4): $1022-1039$.

O’Neill, Brenda, and David K. Stewart. 2009. "Gender and Political Party Leadership in Canada." Party Politics 15 (6): 737-57.

Pilet, Jean-Benoit, and William Cross. 2014. The Selection of Political Party Leaders in Contemporary Parliamentary Democracies: A Comparative Study. New York: Taylor \& Francis.

Pini, Barbara. 2005. “The Third Sex: Women Leaders in Australian Agriculture.” Gender, Work \& Organization 12 (1): 73-88.

Reyes-Housholder, Catherine. 2013. "Presidential Gender and Representation in Cabinets: Do Female Presidents Appoint More Women Than Male Presidents?" Presented at the 2013 Annual Meeting of the American Political Science Association, Chicago.

Reynolds, Andrew. 1999. "Women in the Legislatures and Executives of the World: Knocking at the Highest Glass Ceiling." World Politics 51 (4): 547-72.

Schreiber, Ronnee. 2008. Righting Feminism: Conservative Women and American Politics. New York: Oxford University Press.

Shvedova, Nadezhda. 2002. “Obstacles to Women's Participation in Parliament." Women in Politics: Beyond Numbers. Stockholm: International IDEA.

Siaroff, Alan. 2000. "Women's Representation in Legislatures and Cabinets in Industrial Democracies." International Political Science Review 21 (2): 197-215.

Sjoberg, Laura. 2014. "Feminism." In The Oxford Handbook of Political Leadership, ed. Paul 't Hart and R. A. W. Rhodes. Oxford: Oxford University Press, 72-86. 
Staines, Gail, Carol Tavris, and Toby E. Jayaratne. 1974. "The Queen Bee Syndrome." Psychology Today 7 (8): 55-60.

Stockemer, Daniel, and Manon Tremblay. 2015 "Federalism and Women's Representation: Do Federations have More Women Legislators than Centralized States?" Publius: The Journal of Federalism 544 (4): 605-25.

Studlar, Donley T., and Gary F. Moncrief. 1997. "The Recruitment of Women Cabinet Ministers in the Canadian Provinces." Governance 10 (1): 67-81.

. 1999. "Women's Work? The Distribution and Prestige of Portfolios in the Canadian Provinces." Governance 12 (4): 379-95.

Sykes, Patricia Lee. 2013. "Gendering Prime-Ministerial Power." In Understanding Primeministerial Performance: Comparative Perspectives, ed. Paul Strangio, Paul 't Hart, and James Walter. Oxford: Oxford University Press, 102-24.

. 2014. "Does Gender Matter?" In The Oxford Handbook of Political Leadership, ed. Paul 't Hart and R. A. W. Rhodes. Oxford: Oxford University Press, 690-704.

Tremblay, Manon, and Réjean Pelletier. 2000. "More Feminists or More Women? Descriptive and Substantive Representations of Women in the 1997 Canadian Federal Elections." International Political Science Review 21 (4): 381-405.

- 2001. "More Women Constituency Party Presidents: A Strategy for Increasing the Number of Women Candidates in Canada?" Party Politics 7 (2): 157-90.

Trimble, Linda, and Manon Tremblay. 2012. "Representation of Canadian Women at the Cabinet Table.” Atlantis: Critical Studies in Gender, Culture \& Social Justice 30 (1): $31-45$.

Weller, Patrick. 2014. “The Variability of Prime Ministers." In The Oxford Handbook of Political Leadership, ed. Paul 't Hart and R. A. W. Rhodes. Oxford: Oxford University Press, 489-502.

Wiliarty, Sarah Elise. 2008. "Chancellor Angela Merkel - A Sign of Hope or the Exception the Proves the Rule?" Politics \& Gender 4 (3): 485-96.

Willets, David. 1992. "Modern Conservatism." The Political Quarterly 63 (4): 413-21. 